\title{
Statistical Analysis of Recent and Future Rainfall and Temperature Variability in the Mono River Watershed (Benin, Togo)
}

\author{
Agnidé Emmanuel Lawin ${ }^{1,2}, * \mathbb{C}$, Nina Rholan Hounguè ${ }^{2} \mathbb{D}$, Chabi Angelbert Biaou ${ }^{3}(\mathbb{D}$ and \\ Djigbo Félicien Badou ${ }^{1,2}$ \\ 1 Laboratory of Applied Hydrology, National Water Institute, University of Abomey-Calavi, \\ Cotonou 01 BP 526, Benin; fdbadou@gmail.com \\ 2 West African Science Service Centre on Climate Change and Adapted Land Use (WASCAL), \\ Cotonou 01 BP 526, Benin; rholhu@yahoo.fr \\ 3 Laboratoire Eaux Hydro-Systèmes et Agriculture (LEHSA), Institut International d'Ingénierie de l'Eau et de \\ l'Environnement, Ouagadougou 01 BP 594, Burkina Faso; angelbert.biaou@2ie-edu.org \\ * Correspondence: ewaari@yahoo.fr; Tel.: +229-975-818-09
}

Received: 17 November 2018; Accepted: 27 December 2018; Published: 6 January 2019

\begin{abstract}
This paper assessed the current and mid-century trends in rainfall and temperature over the Mono River watershed. It considered observation data for the period 1981-2010 and projection data from the regional climate model (RCM), REMO, for the period 2018-2050 under emission scenarios RCP4.5 and RCP8.5. Rainfall data were interpolated using ordinary kriging. Mann-Kendall, Pettitt and Standardized Normal Homogeneity (SNH) tests were used for trends and break-points detection. Rainfall interannual variability analysis was based on standardized precipitation index (SPI), whereas anomalies indices were considered for temperature. Results revealed that on an annual scale and all over the watershed, temperature and rainfall showed an increasing trend during the observation period. By 2050, both scenarios projected an increase in temperature compared to the baseline period 1981-2010, whereas annual rainfall will be characterized by high variabilities. Rainfall seasonal cycle is expected to change in the watershed: In the south, the second rainfall peak, which usually occurs in September, will be extended to October with a higher value. In the central and northern parts, rainfall regime is projected to be characterized by late onsets, a peak in September and lower precipitation until June and higher thereafter. The highest increase and decrease in monthly precipitation are expected in the northern part of the watershed. Therefore, identifying relevant adaptation strategies is recommended.
\end{abstract}

Keywords: Mono River watershed; trend analysis; climate

\section{Introduction}

Modifications in the climate as a result of both natural and anthropogenic processes have raised considerable concerns (such as more frequent and intense rainfall, droughts, dry spells, violent winds, etc.), as they induce adverse impacts on several development sectors [1].

In recent decades, weather and climate extremes such as droughts, heat waves, wild fires, floods and storms have increased in frequency and intensity in several regions of the world. In fact, Vincent et al. [2] noticed that the percentage of warm nights is increasing while that of cold nights is decreasing in South-America. In addition, the US Climate Change Science Program underscored the fact that heavy precipitations have become more frequent and intense in Northern America [3]. In central Asia, Savitskaya [4] reported that, during the last 50 years, there was high variability in the pattern of precipitation, whereas winter has become warmer in the entire region. 
Furthermore, in tropical Africa a significant increase in temperature, about $0.15{ }^{\circ} \mathrm{C}$ per decade, was detected over the period 1979-2010 [5]. Consequently, high fatality rates are recorded in developing countries because of their high reliance on natural resources and their limited coping capacities [6]. Several authors highlighted that, since the 1970s, the number of natural disasters (flood, drought, windstorm, epidemic and famine) has been increasing in sub-Saharan Africa [7-9]. In 2012, central and western Africa were hit by severe floods which affected 1,538,242 people and caused 340 deaths as of September of that year. Moreover, flood events of 2010 have been recorded in West Africa as one of the most disastrous during the last decade. In 2010 only, Benin lost about USD 262 million [10], whereas Togo recorded about USD 43.934 million as damage and loss in the same year [11].

Thus, there is a need to carry out future climate analysis in order to foresee potential hazards and ultimately to develop appropriate strategies to combat them. According to the fifth assessment report AR5, "global surface temperature change for the end of the 21st century is likely to exceed $1.5^{\circ} \mathrm{C}$ relative to $1850-1900$ for all RCP scenarios except RCP2.6" [12]. However, it is clear that climate-change impacts will be time and location specific [13]. Therefore, undertaking climate projection at regional and local level will contribute to more accurate and relevant actions towards human security.

As in many other watersheds in the world, climate trend analyses have been carried out in the Mono watershed [14-18]. Ntajal et al. [18] noted that, over the period 1961-2013, at local scale, there is a significant decreasing trend in rainfall at the station of Sokode (upstream), while an insignificant increase in rainfall is observed in the downstream (Atakpame, Sotouboua, Aklakou and Tabligbo). The same assessment was conducted by Amoussou [15] for the period 1961-2000 using a cubic spatial interpolation for rainfall data in the watershed. The results showed an overall decreasing trend of rainfall. So far, however, there are few climate related studies which have addressed future climate projection in the Mono River watershed, despite the fact that people living at the downstream usually experience flood events during rainy seasons. The divergence noted among the results of previous studies makes it important to keep assessing climate trend in the watershed, mainly over a recent period. Therefore, this study aims at assessing current and future climate change in the Mono River watershed.

\section{Materials and Methods}

\subsection{Study Area}

The Mono River watershed occupies an area of $27,822 \mathrm{~km}^{2}$ shared between two West-African countries, Togo and Benin. Specifically, it is located between the latitudes $06^{\circ} 16^{\prime} \mathrm{N}$ and $09^{\circ} 20^{\prime} \mathrm{N}$, and the longitudes $0^{\circ} 42^{\prime} \mathrm{E}$ and $2^{\circ} 25^{\prime} \mathrm{E}$ (Figure 1). The major part of the basin lies in Togo's territory, totaling 21,750 km², whereas that of Benin stretches to $6072 \mathrm{~km}^{2}$. The river serves as natural border between the two countries in the southern part. The climate is tropical (two rainy seasons and two dry seasons) downstream and subequatorial (one rainy season and one dry season) upstream. 

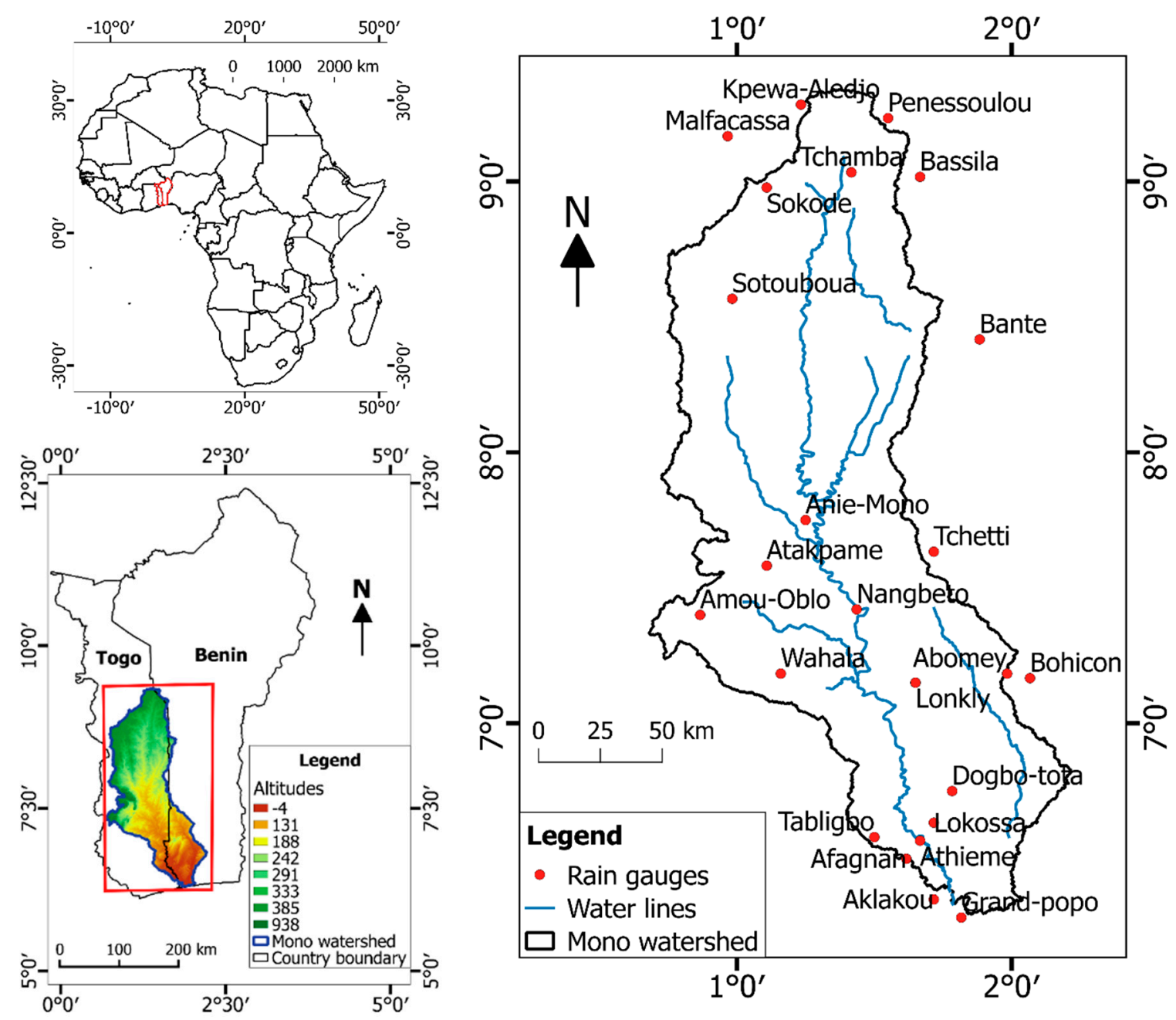

Figure 1. Location of Mono watershed and considered rain gauges.

\subsection{Data Used}

Both observation and projection data were used. Daily observed rainfall and temperature were collected from meteorological institutes of Benin and Togo (DMN, Direction de la Météorologie Nationale) for the period 1981-2010. That period is the current normal used for climatological analysis, and this study aims at taking it into account, as previous studies have already accounted for other normals $[15,17,18]$. As presented by Figure 1, rainfall data were collected at 24 rain gauges within and around Mono watershed (not farther than $25 \mathrm{~km}$ ). As for temperature data, they were collected from three synoptic stations located in the watershed: Tabligbo, Atakpamé and Sokodé.

Projected data were provided by the regional climate model (RCM), REMO (Table 1). Rainfall and temperature data were extracted for the period 2018-2050 and under two representative concentration pathways: RCP4.5 (intermediate pathway) and RCP8.5 (most extreme pathway). Akinsanola et al. [19] have already noticed that REMO fairly simulates rainfall in West Africa and concluded that it can be used for future climate projections in the region. However, the use of a multi-model ensemble approach (more than one model) is recommended in order to better estimate the actual climate and improve the robustness of climate change projections [20-22]. 
Table 1. Characteristics of the regional climate model (RCM), REMO.

\begin{tabular}{ccc}
\hline Model Name & Institute & Driven Model \\
\hline \multirow{2}{*}{ REMO2009 } & Helmholtz-Zentrum Geesthacht, & Max Planck Institute-Earth \\
& Climate Service Center, Max & System Model running on low \\
& Planck Institute for Meteorology & resolution grid (MPI-ESMLR) \\
\hline
\end{tabular}

These data were accessed online (https:/ /www.cordex.org) in the context of the Coordinated Regional Climate Downscaling Experiment (CORDEX) over Africa at $0.44^{\circ}$ resolution.

\subsection{Methods}

\subsubsection{Trend Analysis}

Trends and breakpoints were assessed using the non-parametric test of Mann-Kendall first, followed by the Pettitt and SNH tests The Mann-Kendall test is used in order to establish whether there is a trend (increasing or decreasing) in the time series. It is done with a confidence level of $95 \%$, and the hypotheses are:

$\mathrm{H}_{0}$ : there is no trend in rainfall time series;

$\mathrm{H}_{1}$ : there is a trend in rainfall time series.

For both Pettitt and SNH tests, significance level $\alpha=0.05$, and the hypotheses are:

$\mathrm{H}_{0}$ : there is no change in annual rainfall data;

$\mathrm{H}_{1}$ : there is a date at which there is a change in the data.

Moreover, in order to assess the trend of annual rainfall at watershed scale, and because rainfall data are not measured in every single grid of the watershed, spatial interpolation was required. In the scope of this study, ordinary kriging (OK) was chosen over other methods-such as arithmetic mean, Thiessen polygon, inverse distance weighting - because (i) it takes into account not only the distance between observation stations and estimation point but also the distance between stations taken two by two; (ii) it is a stochastic method which provides the best linear unbiased predictions; (iii) the interpolation error can be estimated [23]. Nonetheless, one of the limitations of kriging is that it is not suitable when there are few observation points. Kriging was basically developed for geostatistics purposes [24] but is widely used in climatology. It is worth noting that the 'backbone' of kriging is the variogram which explains the variance of the studied variable with respect to distance between observation points. Equation (1) presents the formula of variogram

$$
\mathrm{\gamma}(h)=\frac{1}{2 N(h)} \sum_{i=1}^{N(h)}\left(z\left(p_{i}\right)-z\left(p_{i}+h\right)\right)^{2},
$$

where $\mathrm{y}(h)$ is the variogram, $N(h)$ the number of coupled points separated by the distance $h, z\left(p_{i}\right)$ the observed rainfall at location $p_{i}$, and $z\left(p_{i}+h\right)$ the observed rainfall at location $p_{i}+h$.

Furthermore, considering the fact that rainfall regime in Mono watershed is not homogenous, rainfall trend analysis is carried out with respect to three latitude-based regions, as done in previous studies $[15,18]$. The regions are defined as follows: latitude $<7,7 \leq$ latitude $\leq 8$ and latitude $>8$. Hereinafter, these regions are respectively referred to as southern part, central part and northern part of the Mono watershed.

Analysis of temperature trends over the watershed was conducted on the arithmetic mean from the stations of Tabligbo, Sokodé and Atakpamé. 


\subsubsection{Interannual Rainfall Variability Analysis}

The standardized precipitation index (SPI) [25] is a tool recommended by the World Meteorological Organization (WMO) and widely used for quantifying the precipitation deficit over different timescales ( 3 to 48 months). For the selected timescale, rainfall records are fitted with a probability distribution which is then transformed into a normal distribution so that the mean SPI for the location and desired period is zero. Hence, this method improves the common anomaly method (Equation (2)), which does not take into account the fact that rainfall is typically not normally distributed for a cumulative period of 12 months or less.

$$
I(i)=\frac{x_{i}-\overline{x_{m}}}{\sigma}
$$

where $I(i), x_{i}, \overline{x_{m}}$ and $\sigma$ are respectively the standardized index of year $i$, the value for the year $i$, the average and the standard deviation of the time series.

In the present study, the SPI 12 (for 12 month's timescale) is used to assess rainfall deficit or excess on a yearly basis. Moreover, SPI 12 is the one recommended for watershed analysis [26]. Table 2 presents the guidelines for analyzing SPI values $[25,26]$.

Table 2. Standardized precipitation index (SPI) values and their meanings.

\begin{tabular}{cc}
\hline SPI Value & Meaning \\
\hline 2.0 and plus & Extremely wet \\
1.5 to 1.99 & Very wet \\
1.0 to 1.49 & Moderately wet \\
-0.99 to 0.99 & Near normal \\
-1 to -1.49 & Moderately dry \\
-1.5 to -1.99 & Severely dry \\
-2 and less & Extremely dry \\
\hline
\end{tabular}

\subsubsection{Future Climate Analysis}

Raw outputs from RCMs must be corrected prior to local impact studies because of the bias they encompass. There are several bias correction methods but in this study, the methods of delta, linear scaling and empirical quantile mapping $(\mathrm{EQM})$ are used because they have produced satisfactory results in previous studies carried out in similar climatic regions [27-29]. The results of Ntcha M'po et al. [27], Essou and Brissette [30] and Speth et al. [31], who bias-corrected REMO data in the Ouémé watershed (Benin), guided the choice of correction methods in this study. Rainfall was corrected with delta method in the south, multiplicative scaling in the central part and EQM in the north. As for temperature data, they were corrected using only EQM.

\subsubsection{Percentage of Relative Change in Rainfall Seasonal Cycle}

It is computed using Equation (3).

$$
P_{c, m}=\frac{R_{p r o j, m}-R_{o b s, m}}{R_{o b s, m}} \times 100
$$

where, $P_{c, m}, R_{p r o j, m}$ and $R_{o b s, m}$ are respectively the percentage of change for $m$ th month, average projected rainfall for month $\mathrm{m}$, and the average rainfall of month $\mathrm{m}$ during observation period. 


\section{Results and Discussion}

\subsection{Trends and Interannual Variability in Rainfall}

\subsubsection{Present Rainfall Pattern}

The pattern of monthly rainfall varies from one part of the watershed to the other. The southern and northern parts are respectively characterized by bimodal and unimodal rainfall regime, whereas, a transitory (neither bimodal nor unimodal) regime was found in the central region (Figure 2).

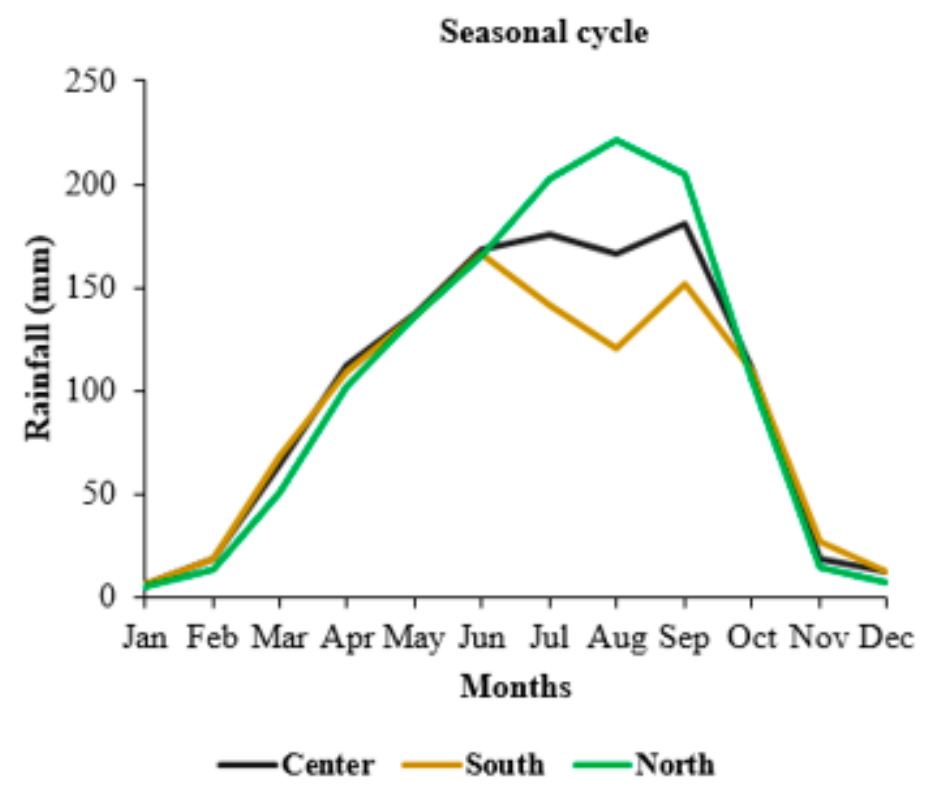

Figure 2. Rainfall seasonal cycles in Mono watershed.

In the south, two peaks are respectively recorded in June and September, while the unique peak in the northern part occurs in August. On the other side, the rainy season in the central part lasts from March to September. These results are in line with previous research findings $[15,17,18]$. Thus, the bimodal or unimodal characteristics of the precipitation regime seem not to change over the recent periods compared to the historical period.

The results of the Mann-Kendall test (Table 3) underscored the fact that rainfall in the three regions of Mono watershed had an increasing trend during the period 1981 to 2010.

Table 3. Results of break-point detection and Mann-Kendall test on observed rainfall.

\begin{tabular}{|c|c|c|c|c|c|}
\hline \multirow{2}{*}{ Region } & \multicolumn{3}{|c|}{ Break-Point Detection } & \multicolumn{2}{|c|}{ Mann-Kendall Test } \\
\hline & Tests & Break-Point & $p$-Value & $p$-Value & Sen's Slope \\
\hline \multirow{2}{*}{ South } & Pettitt & 2001 & 0.0695 & \multirow{2}{*}{0.0022} & \multirow{2}{*}{9.99} \\
\hline & $\mathrm{SNH}$ & 2001 & 0.0497 & & \\
\hline \multirow{2}{*}{ Centre } & Pettitt & 1987 & 0.3113 & \multirow{2}{*}{0.0385} & \multirow{2}{*}{7.56} \\
\hline & $\mathrm{SNH}$ & 1983 & 0.0217 & & \\
\hline \multirow{2}{*}{ North } & Pettitt & 1987 & 0.0952 & \multirow{2}{*}{0.0295} & \multirow{2}{*}{6.49} \\
\hline & $\mathrm{SNH}$ & 1983 & 0.0025 & & \\
\hline
\end{tabular}

As presented in Table 3 and Figure 3, the SNH test detected break points in the time series while the Pettitt test did not. 
The change noted in the center and the north may be related to the well-known 1970s and 1980s droughts which affected many West-African countries and was documented by several authors such as Le Barbé and Lebel [32], Le Barbé et al. [33] and Le lay and Galle [34].
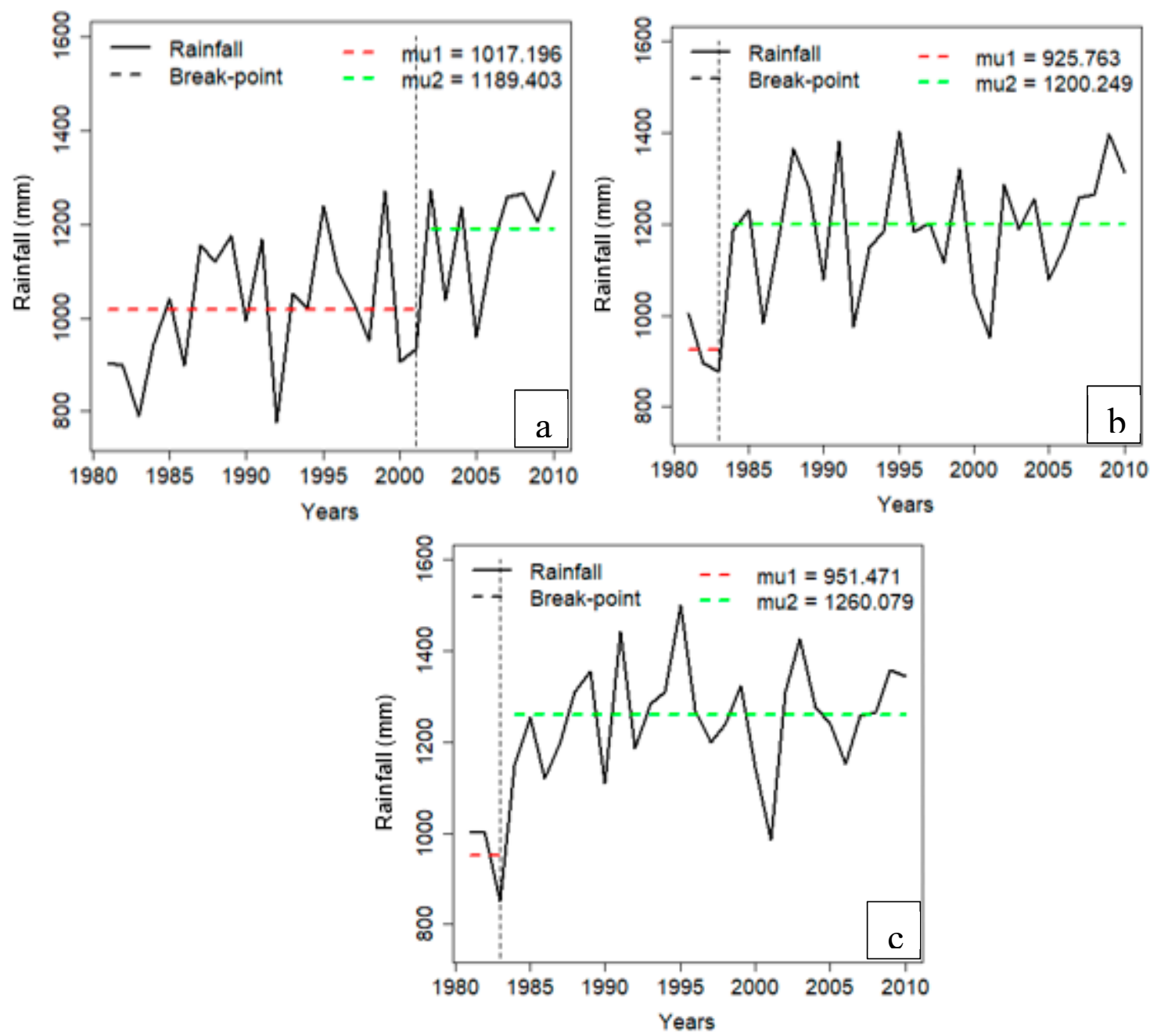

Figure 3. Standardized Normal Homogeneity (SNH) test on observed annual rainfall time series in the south (a), center (b) and north (c).

Figure 4 presents the results of the SPI computation.

According to the baseline period, the longest dry period is 1981-1986 in the south, 1981-1983 in the central part and 1981-1984 in the north. In addition, the driest year is 1992 in the south, and 1983 for both the center and north. As for years of highest excess, it is 2010 in the south and 1995 in central and northern parts. It is worth noting that, in the three regions, the longest dry period falls in the 1980s drought events. After this specific period no extreme drought occurred (except in 1992 in the south), and there were more years above normal than below. Overall, the period after 1990 is characterized by more wet years, and it explains the trends highlighted by statistical tests performed above. Similar results have been reported in other watersheds in West Africa by several authors, such as Adeyeri et al. [35] in Komadugu-Yobe basin, Nicholson et al. [36] over West Africa, Ozer et al. [37] over the Sahelian region, and by Lawin [38] and Attogouinon et al. [39] in the upper Ouémé river valley. However, this shift to wetter condition is region dependent, because other studies reported a decreasing trend in rainfall patterns over West-Africa $[40,41]$. 

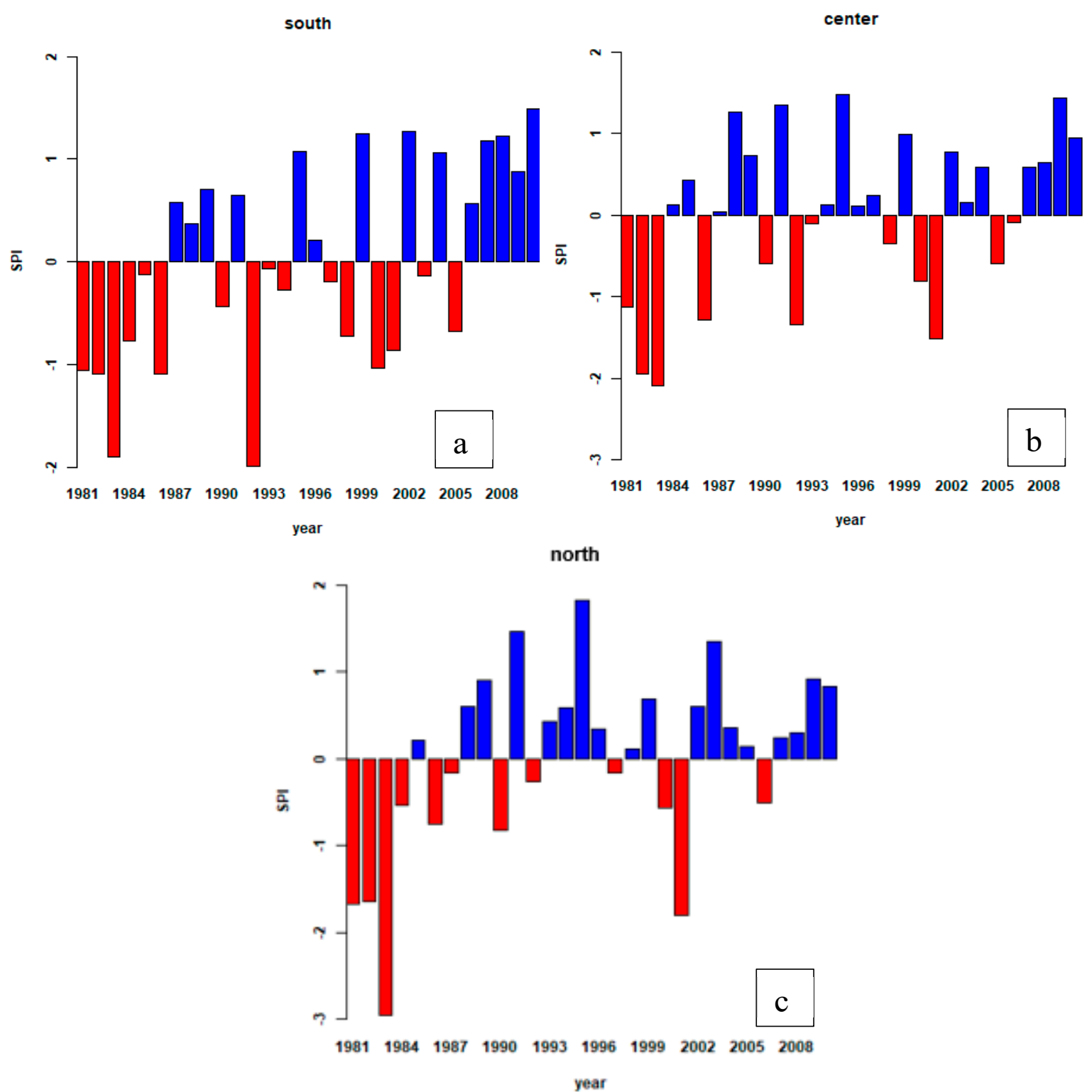

Figure 4. Standardized precipitation index of observed annual rainfall in the south (a), center (b) and north $(\mathbf{c})$.

\subsubsection{Future Rainfall Pattern}

The results of break-point detection and the Mann-Kendall test performed on annual rainfall under RCP4.5 and RCP8.5 are summarized in Table 4.

The results of homogeneity tests and the Mann-Kendall test suggest that, all over the watershed, there is neither break-point nor a linear trend in annual rainfall time series, under emission scenarios RCP4.5 and RCP8.5. Statistically, rainfall time series are homogenous and present no trend. Nonetheless, some variabilities are observed. Specifically, in the northern part and for RCP8.5, rainfall might decrease by 2035 and increase thereafter. The increase in annual precipitation over recent decades in Mono river watershed seems not to be maintained in the future. Future pattern of rainfall may be marked by high variabilities. Such an absence of significant trend in rainfall is also reported by N'Tcha M'Po et al. [40] in Ouémé river basin by 2050, using a REMO model. Similarly, Lawin et al. [42] reported no trend in rainfall pattern in the Imbo north plain region in Burundi under central Africa climatology using an ensemble of eight regional climate models. 
Table 4. Results of break-point detection and Mann-Kendall test on annual rainfall under RCP4.5 and RCP8.5.

\begin{tabular}{|c|c|c|c|c|c|c|}
\hline \multirow{2}{*}{ Scenario } & \multirow{2}{*}{ Region } & \multicolumn{3}{|c|}{ Break-Point Detection } & \multicolumn{2}{|c|}{ Mann-Kendall Test } \\
\hline & & Result & Break-Point & $p$-Value & $p$-Value & Sen's Slope \\
\hline \multirow{6}{*}{$\mathrm{RCP} 4.5$} & \multirow{2}{*}{ South } & Pettitt test & 2021 & 0.621 & \multirow{2}{*}{0.914} & \multirow{2}{*}{-0.097} \\
\hline & & SNH test & 2049 & 0.942 & & \\
\hline & \multirow{2}{*}{ Center } & Pettitt test & 2033 & 0.346 & \multirow{2}{*}{0.285} & \multirow{2}{*}{2.293} \\
\hline & & SNH test & 2033 & 0.525 & & \\
\hline & \multirow{2}{*}{ North } & Pettitt test & 2031 & 0.129 & \multirow{2}{*}{0.091} & \multirow{2}{*}{4.427} \\
\hline & & SNH test & 2031 & 0.155 & & \\
\hline \multirow{6}{*}{ RCP8.5 } & \multirow{2}{*}{ South } & Pettitt test & 2029 & 0.0731 & \multirow{2}{*}{0.588} & \multirow{2}{*}{-1.510} \\
\hline & & SNH test & 2024 & 0.842 & & \\
\hline & \multirow{2}{*}{ Center } & Pettitt test & 2029 & 0.673 & \multirow{2}{*}{0.653} & \multirow{2}{*}{-1.341} \\
\hline & & SNH test & 2029 & 0.712 & & \\
\hline & \multirow{2}{*}{ North } & Pettitt test & 2041 & 0.324 & \multirow{2}{*}{0.394} & \multirow{2}{*}{3.296} \\
\hline & & SNH test & 2041 & 0.104 & & \\
\hline
\end{tabular}

The SPI computed for each region emphasizes this variability (Figure 5).

Under RCP4.5, the number of projected deficit years in the watershed increases slightly from south to north. The years 2020 and 2024 are projected to be extremely wet in the south, whereas 2031 is expected to be extremely dry in the north. However, under RCP8.5, the projected number of deficit years decreases from south to north. The year 2033 is projected to be extremely dry in the north, and again, years 2020 and 2024 for this scenario are expected to be extremely wet in the south. The agreement of both scenarios for years 2020 and 2024 shows that those years will potentially be characterized by extreme precipitations. Furthermore, from south to north, RCP8.5 projects more extremely wet years than RCP4.5.

Furthermore, the pattern of the seasonal cycle of rainfall is expected to undergo some modifications. In the southern part (Figure 6a), rainfall seasonal cycle is projected to keep its bimodal pattern under RCP4.5 and RCP8.5. In addition, both scenarios project almost the same pattern. As in the normal period, the first peak is recorded in June but with a slightly lower amount. The second peak, which normally occurs in September, is expected to extend to October with a higher value.

In the central and northern parts (Figure $6 \mathrm{~b}, \mathrm{c}$ ), and under RCP4.5 and RCP8.5, the rainfall regime is projected to be characterized by late onsets and lower precipitation until June, compared to observations, and higher thereafter. Both scenarios converge on the fact that rainfall peak will probably occur in September. The northern part is expected to keep its unimodal pattern under both scenarios, whereas a shift from a transitional regime to a unimodal one is expected in the central region.

Projected future rainfall regimes under the two scenarios are quite similar, apart from in August, where RCP4.5 predicted a slightly larger amount than RCP8.5, and an inverse proportion was predicted in June

Moreover, on a monthly scale, Figure 7 depicts how the rainfall seasonal cycle is expected to change under RCP4.5 and RCP8.5 compared to the baseline period.

Under RCP4.5, the relative change in monthly rainfall varies from $-5.5 \%$ to $8.4 \%$ in the southern part, $-29.9 \%$ to $22.2 \%$ in the central part and $-39 \%$ to $91.4 \%$ in the northern part. For RCP 8.5 , the expected change ranges from $-3.5 \%$ to $5.8 \%$ in the southern part, $-55 \%$ to $20 \%$ in the central part and $-64 \%$ to $85.9 \%$ in the northern part. Therefore, the biggest changes (both increase and decrease) in monthly rainfall are expected in the northern part of the watershed, regardless of the scenario considered. According to RCP4.5 and with respect to the observation period, the highest rainfall decrease during the period 2018-2050 is expected to occur in February, whereas January and November will record the highest increases. 

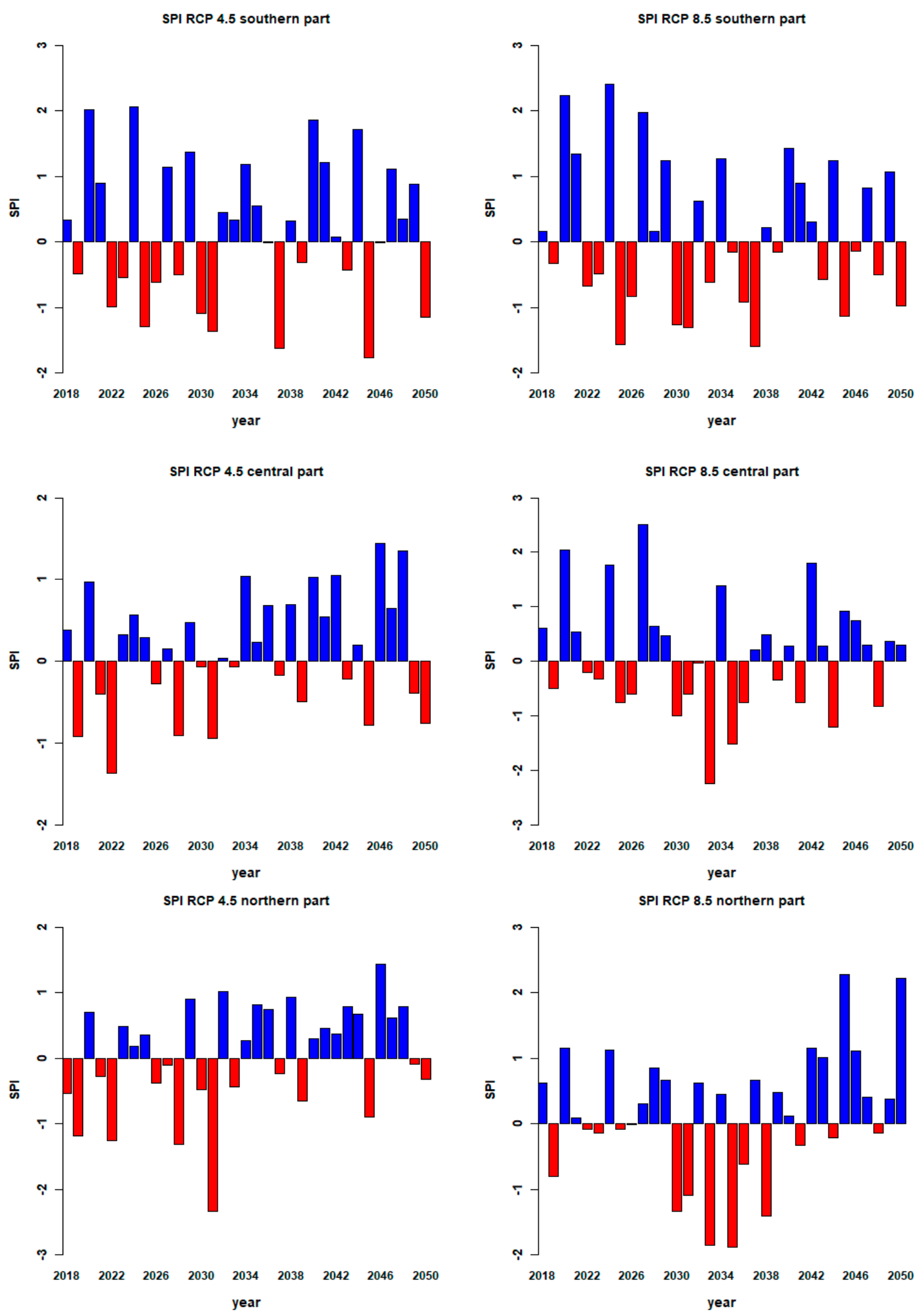

Figure 5. Standardized precipitation index of annual rainfall under RCP4.5 (left panel) and RCP8.5 (right panel). 

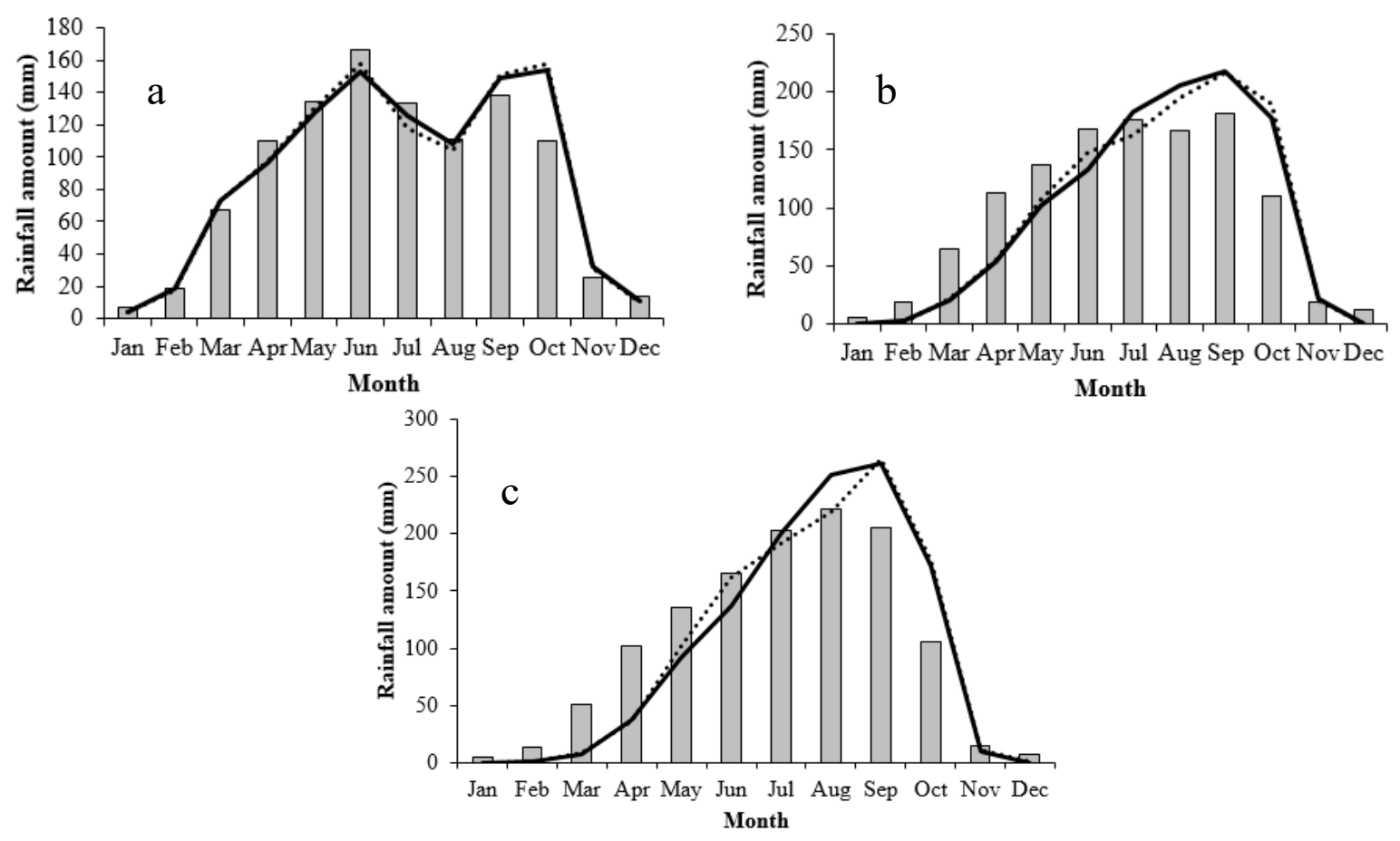

Observation 1981-2010

RCP4.5 $\cdots \cdots \cdot$ RCP8.5

Figure 6. Seasonal cycles of rainfall in the south (a), center (b) and north (c) under RCP4.5 and RCP8.5.

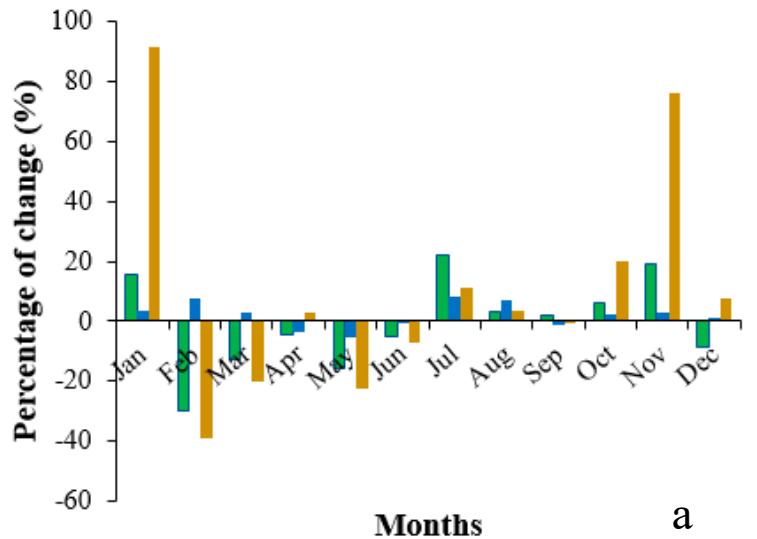

$\square$ Center $\square$ South $\square$ North

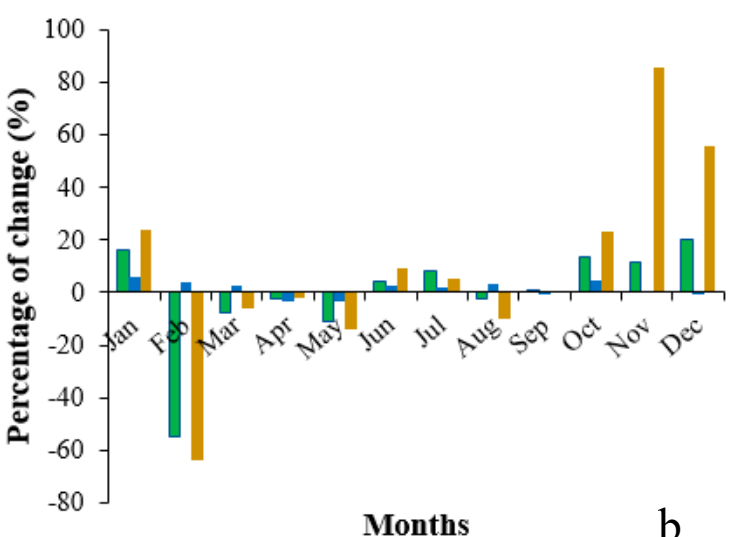

$\square$ Center $\square$ South $\square$ North

Figure 7. Expected change in rainfall seasonal cycles under RCP4.5 (a) and RCP8.5 (b).

Under RCP8.5, the highest decrease is projected to affect rainfall in February, whereas the highest increase is expected in November. Thus, the two scenarios project more than $70 \%$ increase of rainfall in the month of November by 2050, compared to the observation period. In addition, the highest increase is projected by RCP4.5 and the highest decrease by RCP8.5. Globally substantial changes are expected prior to and at the end of rainy seasons.

\subsection{Temperature Trend}

\subsubsection{Present Temperature Change}

The two homogeneity tests performed on annual temperature revealed the presence of break-point in the time series (Figure 8). 

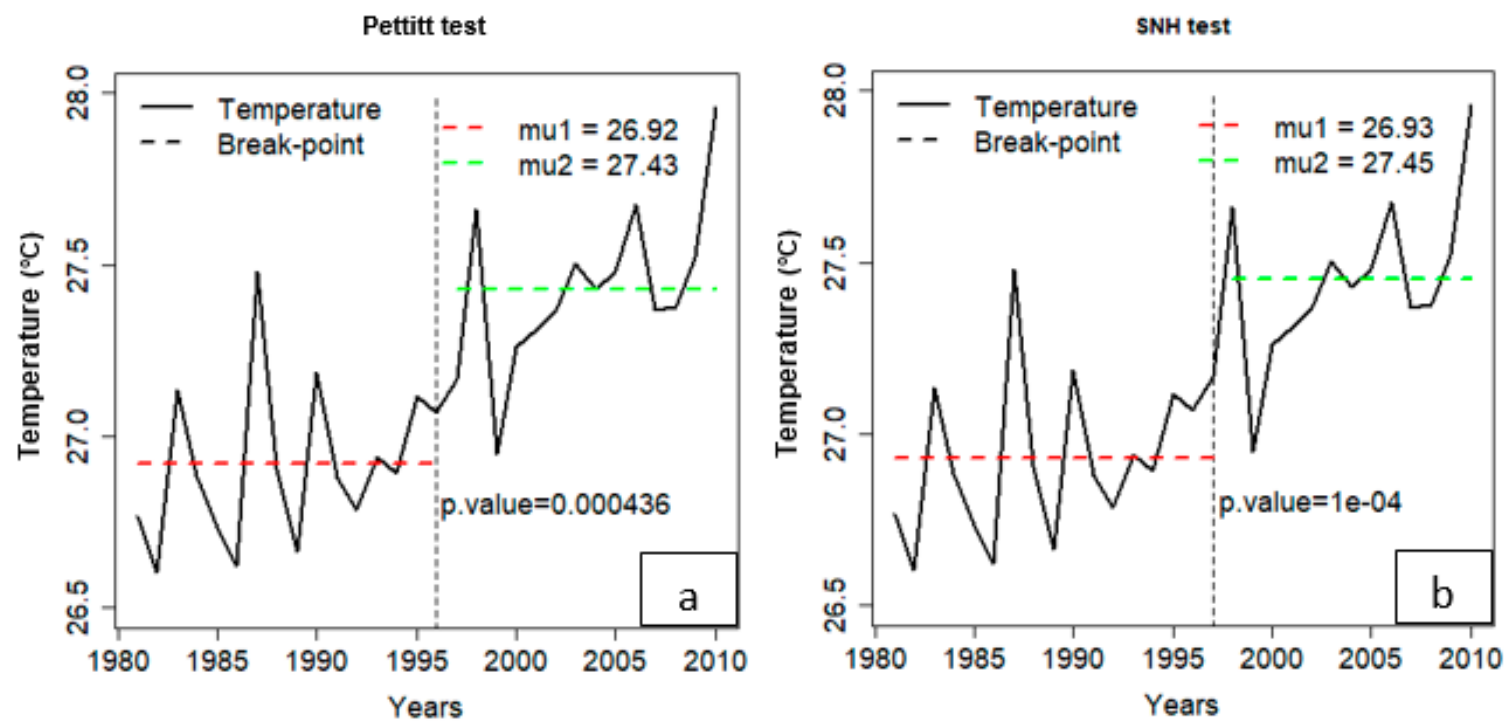

Figure 8. Pettit test (a) and SNH test (b) performed on annual temperature over the period 1981-2010.

The Pettitt test indicates that since 1996 mean annual temperature has increased by $0.51{ }^{\circ} \mathrm{C}$ in Mono watershed compared to the period 1981-1995, whereas the results of the SNH test implies an increase of $0.52{ }^{\circ} \mathrm{C}$ from the period 1981-1996 to 1997-2010. In addition, the Mann-Kendall test suggested a significant increasing trend ( $p$-value $=3.457 \times 10^{-6}$ and $\left.\tau=0.6\right)$.

Anomalies computation revealed that, from 1981 to 1997, temperature was globally below and near normal, but since 1998 it has stayed above the normal (Figure 9).

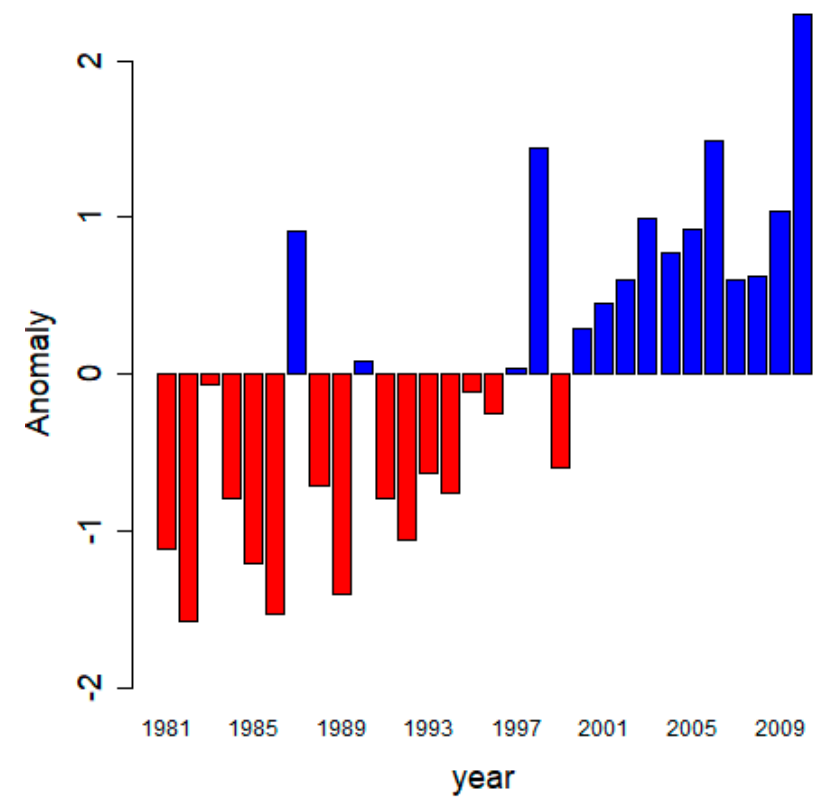

Figure 9. Anomaly of mean annual temperature in Mono watershed.

It therefore corroborates the outputs from homogeneity tests. In addition, these results are in line with previous studies which noted similar increasing trend of temperature in West Africa (Badjana [43] in the Kara river basin of Togo, Kabo-Bah et al. [44] in the Ghana part of Volta river basin, Oguntunde et al. [45] at Ibadan and Collins [5] over the West-African region). 


\subsubsection{Future Temperature Change}

Under RCP4.5, the homogeneity tests detected break-points at different dates, but they got an agreement under RCP8.5 (Figure 10). Under the intermediate scenario, the Pettitt test indicated that, from the period 2018-2031 to 2032-2050, temperature may increase by $0.36{ }^{\circ} \mathrm{C}$. On the other side, $\mathrm{SNH}$ test projected an increase of $0.39^{\circ} \mathrm{C}$ from $2018-2027$ to 2028-2050. For the high pathway scenario, both tests agreed on an increase of $0.87^{\circ} \mathrm{C}$ from the period 2018-2038 to 2039-2050.
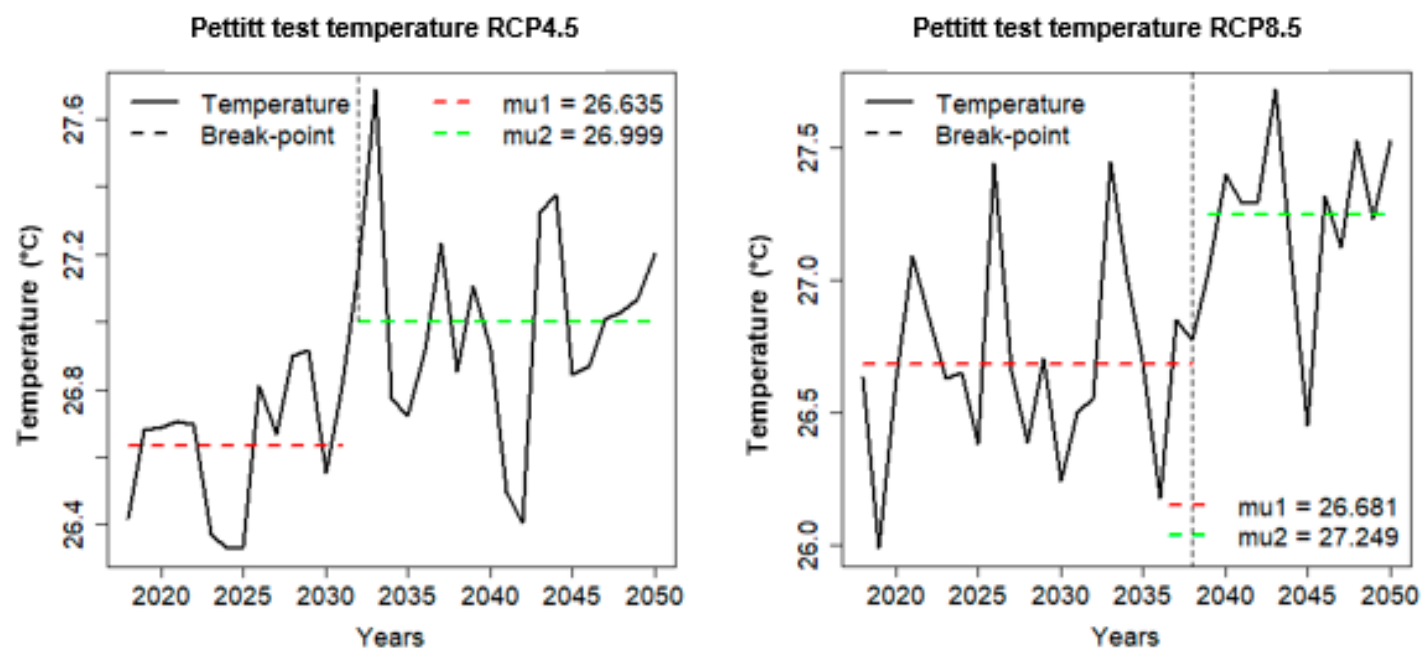

SNH test temperature RCP4.5
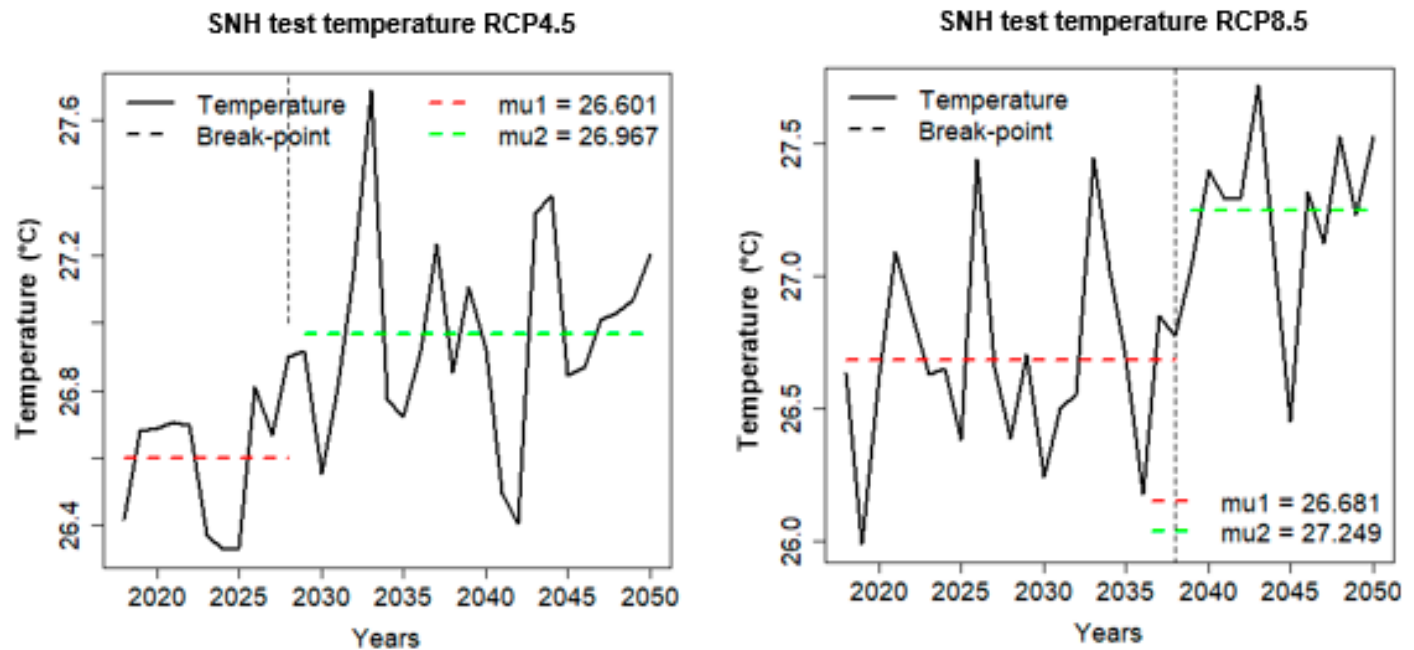

Figure 10. Pettitt test (upper panel) and SNH test (lower panel) performed on temperature under RCP4.5 and RCP8.5.

Regardless of the scenario used, an overall significant increasing trend in temperature is expected by 2050 (Table 5).

Figure 11 depicts anomalies of temperature under RCP4.5 and RCP8.5.

For both emission scenarios, the number of years above normal is higher compared to the number of years below normal. Therefore, future climate in Mono river watershed is projected to be warmer by 2050 . Such an increasing trend by 2050 has been reported by Nelson et al. [46] in Togo. Similarly, Oyerinde [47] reported a consistently increasing trend in temperature over the Niger River Basin, $5 \%$ to $10 \%$ under RCP4.5 and 5\% to $20 \%$ under RCP8.5, using an ensemble model from eight regional climate models. In the Massili basin of Burkina Faso, Bontogho [29] reported an increase in temperature by $1.8^{\circ} \mathrm{C}$ (RCP4.5) and $3.0^{\circ} \mathrm{C}$ (RCP8.5) from 1971 to 2050 using the regional model HIRHAM5. Badou [48] reported a temperature increase of up to $0.48^{\circ} \mathrm{C}$ under RCP4.5 and up to $0.45{ }^{\circ} \mathrm{C}$ under RCP8.5 using 
the REMO model in the Benin part of Niger River basin. Overall, all models and scenarios considered by several authors converge to a moderate to high increase of temperature all over the world.

Table 5. Results of Mann-Kendall test on annual temperature under RCP4.5 and RCP8.5.

\begin{tabular}{cccccc}
\hline \multirow{2}{*}{ Scenario } & \multicolumn{3}{c}{ Break-Point Detection } & \multicolumn{2}{c}{ Mann-Kendall Test } \\
\cline { 2 - 6 } & Result & Break-Point & $p$-Value & $\boldsymbol{p}$-Value & Sen's Slope \\
\hline \multirow{2}{*}{ RCP4.5 } & Pettit test & 2031 & 0.0039 & 0.0003 & 0.017 \\
& SNH test & 2027 & 0.0103 & 0.028 \\
\hline \multirow{2}{*}{ RCP8.5 } & Pettitt test & 2038 & 0.0082 & \multirow{2}{*}{0.0009} & \multirow{2}{*}{0.028} \\
& SNH test & 2038 & 0.0029 & & \\
\hline
\end{tabular}

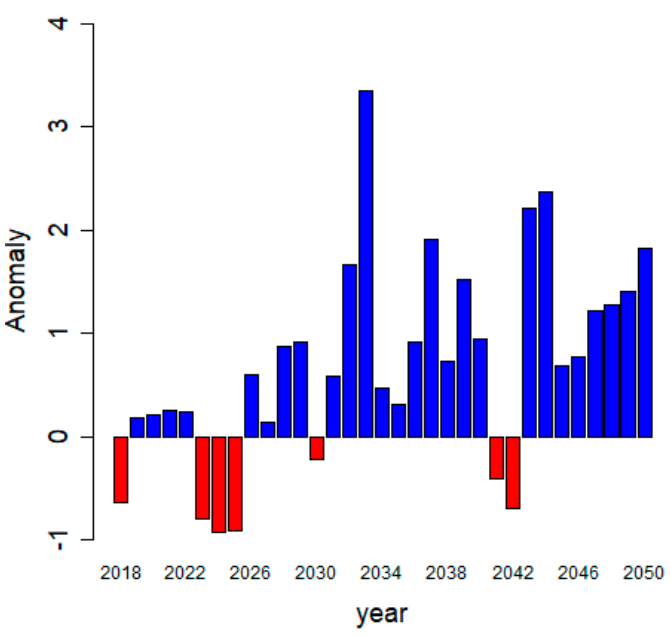

(a)

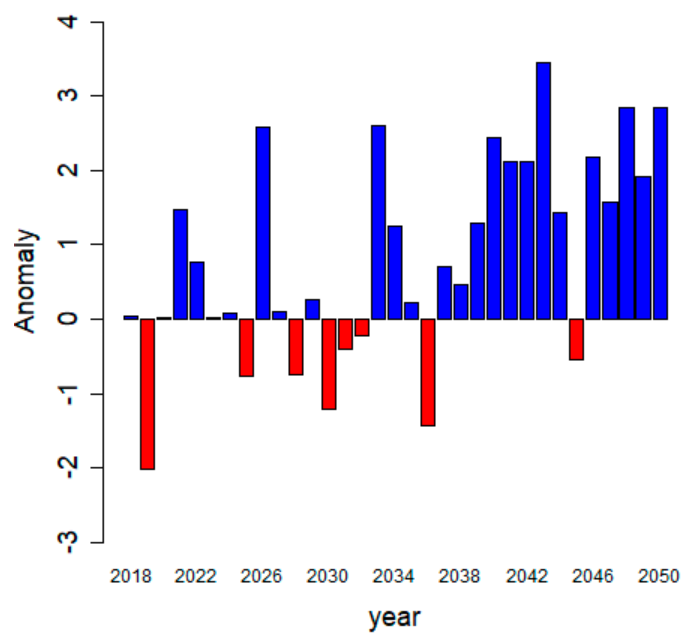

(b)

Figure 11. Temperature anomaly under RCP4.5 (a) and RCP8.5 (b).

\section{Conclusions}

This paper examined the trend in annual rainfall and annual temperature of Mono river watershed over the observation period 1981-2010 and by 2050 using the regional model REMO under RCP4.5 and RCP8.5. It also assessed the monthly pattern of rainfall over the same periods. During the last three decades, rainfall and temperature have been increasing all over the Mono River watershed. By 2050 and under emission scenarios RCP4.5 and RCP8.5, annual rainfall is projected to be characterized by high variability, whereas a significant increasing trend is projected for annual temperature (warmer future climate). For each of the three defined regions (south, center and north), and under both emission scenarios, the seasonal cycle of rainfall is expected to change: In the southern part, the first peak is projected to reduce slightly, whereas the second peak is expected to increase and shift to October; however, in the central and northern parts, it is expected that there will be late onset of rainfall and higher peaks. In addition, the seasonal cycle of rainfall in the central part is expected to shift from a transitional regime to a unimodal one. Moreover, on a monthly scale, the northern part of the watershed is expected to record the highest increase and decrease in rainfall regardless of the emission scenario considered. These considerable changes in the monthly rainfall of the northern part are expected to occur globally in the dry season, thus indicating potential extreme events. Considering the projected trends and patterns for rainfall and temperature over Mono watershed by 2050, it is recommended that experts identify and implement relevant adaptation strategies. 
Author Contributions: A.E.L., N.R.H., D.F.B. and C.A.B. designed the study, developed the methodology and wrote the original manuscript. N.R.H. performed the field work, data collection and computer analyzis, meanwhile C.A.B. contributed to results analysis and interpretation. Overall the authors contributed equally to this paper.

Funding: This research was funded by the West African Science Service Center for Climate Change and Adapted Land use (WASCAL).

Acknowledgments: Authors thank the German Federal Ministry of Education who funded the Master Degree of Nina Rholan Houngue through the West African Science Service Center for Climate Change and Adapted Land use (WASCAL). We thank the ESGF grid (http://esg-dn1.nsc.liu.se/esgf-web-fe/) which provided the CORDEX-Africa future climate projections.

Conflicts of Interest: The authors declare no conflict of interest.

\section{References}

1. Intergovernmental Panel on Climate Change (IPCC). Climate Change 2007: Synthesis Report. An Assessment of the Intergovernmental Panel on Climate Change; IPCC: Valencia, Spain, 2007.

2. Vincent, L.A.; Peterson, T.C.; Barros, V.R.; Marino, M.B.; Rusticucci, M.; Carrasco, G.; Ramirez, E.; Alves, L.M.; Ambrizzi, T.; Berlato, M.A.; et al. Observed Trends in Indices of Daily Temperature Extremes in South America 1960-2000. J. Clim. 2005, 18, 5011-5024. [CrossRef]

3. Climate Change Science Program (CCSP). Weather and Climate Extremes in a Changing Climate. Regions of Focus: North America, Hawaii, Caribbean, and U.S. Pacific Islands; Karl Thomas, R., Meehl Gerald, A., Miller Christopher, D., Hassol Susan, J., Waple Anne, M., Murray, W.L., Eds.; Department of Commerce, NOAA's National Climatic Data Center: Washington, DC, USA, 2008.

4. Savitskaya, D. Statistical picture of climate changes in Central Asia: Temperature, precipitation, and river flow. In Proceedings of the International Environmental Modelling and Software Society (iEMSs) 2010 International Congress on Environmental Modelling and Software Modelling for Environment's Sake, Ottawa, ON, Canada, 5-8 July 2010; Swayne, D.A., Yang, W., Voinov, A.A., Rizzoli, A., Filatova, T., Eds.; iEMS: Manno, Switzerland, 2010.

5. Collins, J.M. Temperature Variability over Africa. J. Clim. 2011, 24, 3649-3666. [CrossRef]

6. Ahmed, S.A.; Diffenbaugh, N.S.; Hertel, T.W. Climate volatility deepens poverty. Environ. Res. Lett. $2009,4$. [CrossRef]

7. Bhavnani, R.; Vordzorgbe, S.; Owor, M.; Bousquet, F. Disaster Risk Reduction in the Sub-Saharan Africa Region; Commission of the African Union: Washington, DC, USA, 2008.

8. Badou, D.F.; Kapangaziwiri, E.; Diekkrüger, B.; Hounkpè, J.; Afouda, A. Evaluation of recent hydro-climatic changes in four tributaries of the Niger River Basin (West Africa). Hydrol. Sci. J. 2017, 62, 715-728. [CrossRef]

9. Hounkpè, J.; Diekkrüger, B.; Badou, D.F.; Afouda, A.A. Change in Heavy Rainfall Characteristics over the Ouémé River Basin, Benin Republic, West Africa. Climate 2016, 4, 15. [CrossRef]

10. United Nations Development Programme (UNDP). Inondations au Bénin: Rapport D'évaluation des Besoins Post Catastrophe; World Bank: Cotonou, Benin, 2011.

11. United Nations Development Programme (UNDP). Evaluation des Dommages, Pertes et Besoins de Reconstruction Post Catastrophes des Inon-Dations de 2010 au Togo; World Bank: Lomé, Togo, 2010.

12. Intergovernmental Panel on Climate Change (IPCC). Climate Change 2013: The Physical Science Basis. Working Group I Contribution to the IPCC Fifth Assessment Report; Stocker, T.F., Qin, D., Plattner, G.-K., Tignor, M., Allen, S.K., Boschung, J., Nauels, A., Xia, Y., Bex, V., Midgley, P.M., Eds.; IPCC: Cambridge, UK, 2013.

13. Intergovernmental Panel on Climate Change (IPCC). Climate Change 2014: Synthesis Report. Approved Summary for Policymakers; Pachauri, R.K., Meyer, L., IPCC, Eds.; IPCC: Cambridge, UK; Geneva, Switzerland, 2014.

14. Klassou, S.D. Evolution Climato-Hydrologique Récente et Conséquences sur L'environnement: L'exemple du Bassin Versant du Fleuve Mono (Togo-Bénin). Ph.D. Dissertation, Bordeaux III, Université Michel de Montaigne, Pessac, France, 1996.

15. Amoussou, E. Variabilité Pluviométrique et Dynamique Bassin Versant du Complexe la Gunaire Mono-Ahémé-Couffo (Afrique de l'Ouest). Ph.D. Dissertation, Université de Bourgogne, Dijon, France, 2010.

16. Gbeyetin, F.J. Inondations Dans la Basse Vallée du Mono: Typologie et Manifestations. Master's Thesis, Université d'Abomey-Calavi, Cotonou, Benin, 2014.

17. Kissi, A.E. Flood Vulnerability Assessment in Downstream Area of Mono Basin; Université de Lomé: Lomé, Togo, 2014. 
18. Ntajal, J.; Lamptey, B.L.; Sogbedji, M.J.; Wilson-bahun, K.K. Rainfall trends and flood frequency analyses in the lower Mono River basin in Togo, West Africa. Int. J. Des. Ris. Red 2017, 23, 93-103. [CrossRef]

19. Akinsanola, A.A.; Ogunjobi, K.O.; Gbode, I.E.; Ajayi, V.O. Assessing the Capabilities of Three Regional Climate Models over CORDEX Africa in Simulating West African Summer Monsoon Precipitation. Adv. Meteorol. 2015, 2015, 1-13. [CrossRef]

20. Lambert, S.J.; Boer, G.J. CMIP1 evaluation and intercomparison of coupled climate models. Clim. Dyn. 2001, 17, 83-106. [CrossRef]

21. Diallo, I.; Sylla, M.B.; Giorgi, F.; Gaye, A.T.; Camara, M. Multimodel GCM-RCM Ensemble-Based Projections of Temperature and Precipitation over West Africa for the Early 21st Century. Int. J. Geophys. 2012, 2012. [CrossRef]

22. Giorgi, F.; Coppola, E. Does the model regional bias affect the projected regional climate change? An analysis of global model projections A letter. Clim. Chang. 2010, 100, 787-795. [CrossRef]

23. Oliver, M.A.; Webster, R. Kriging: A method of interpolation for geographical information systems. Int. J. Geogr. Inf. Syst. 1990, 4, 312-332. [CrossRef]

24. Matheron, G. Principles of geostatistics. Econ. Geol. 1963, 58, 1246-1266. [CrossRef]

25. Mckee, T.B.; Doesken, N.J.; Kleist, J. The relationship of drought frequency and duration to time scales. In Proceedings of the Eighth Conference on Applied Climatology, Anaheim, CA, USA, 17-22 January 1993; pp. 179-184.

26. WMO. Standardized Precipitation Index User Guide; Svoboda, M., Hayes, M., Wood, D., Eds.; WMO: Geneva, Switzerland, 2012.

27. N’Tcha M'Po, Y.; Lawin, A.E.; Oyerinde, G.T.; Yao, B.K.; Afouda, A.A. Comparison of Daily Precipitation Bias Correction Methods Based on Four Regional Climate Model Outputs in Ouémé Basin, Benin. Hydrology 2016, 4, 58-71. [CrossRef]

28. Obada, E.; Alamou, E.A.; Chabi, A.; Zandagba, J.; Afouda, A. Trends and Changes in Recent and Future Penman-Monteith Potential Evapotranspiration in Benin (West Africa). Hydrology 2017, 4, 38. [CrossRef]

29. Bontogho, T.-N.P.E. Modeling a Sahelian Water Resource Allocation under Climate Change and Human Pressure: Case of Loumbila dam in Burkina Faso. Ph.D. Dissertation, Université d'Abomey-Calavi, Cotonou, Benin, 2015.

30. Essou, G.R.C.; Brissette, F. Climate Change Impacts on the Ouémé River, Benin, West Africa. Earth Sci. Clim. Chang. 2013, 4, 2-11. [CrossRef]

31. Speth, P.; Christoph, M.; Diekkrüger, B. Impacts of Global Change on the Hydrological Cycle in West and Northwest Africa; Springer: Berlin/Heidelberg, Germany, 2010; ISBN 9783642129568.

32. Le Barbé, L.; Lebel, T. Rainfall climatology of the HAPEX-Sahel region during the years 1950-1990. J. Hydrol. 1997. [CrossRef]

33. Le Barbé, L.; Lebel, T.; Tapsoba, D. Rainfall Variability in West Africa during the Years 1950-1990. J. Clim. 2002, 15, 187-202. [CrossRef]

34. Le lay, M.; Galle, S. Variabilité interannuelle et intra-saisonnière des pluies aux échelles hydroloques. La mousson ouest- africaine en climat saoudien. J. Sci. Hydrol. 2005, 50, 209-224.

35. Adeyeri, O.E.; Lamptey, B.L.; Lawin, A.E.; Sanda, I.S. Spatio-Temporal Precipitation Trend and Homogeneity Analysis in Komadugu-Yobe Basin, Lake Chad Region. J. Climatol. Weather Forecast. 2017, 5, 1-12. [CrossRef]

36. Nicholson, S.E.; Some, B.; Kone, B. An Analysis of Recent Rainfall Conditions in West Africa, Including the Rainy Seasons of the 1997 El Nino and the 1998 La Nina Years. J. Clim. 2000, 13, 2628-2640. [CrossRef]

37. Ozer, P.; Erpicum, M.; Demaree, G.; Vandiepenbeeck, M. Discussion of “Analysis of a Sahelian annual rainfall index from 1896 to 2000; the drought continues" The Sahelian drought may have ended during the 1990s. Hydrol. Sci. J. 2003, 48, 489-496. [CrossRef]

38. Lawin, A.E. Analyse Climatologique et Statistique du Regime Pluviométrique de la Haute Vallee de L'ouémé à Partir des Données Pluviographiques AMMA-CATCH Bénin. Ph.D. Dissertation, Institut National Polytechnique de Grenoble, Université d'Abomey-Calavi, Cotonou, Benin, 2007.

39. Attogouinon, A.; Lawin, E.A.; N’Tcha M'Po, Y.; Houngue, R. Extreme Precipitation Indices Trend Assessment over. Hydrology 2017, 4, 36. [CrossRef]

40. N’Tcha M’Po, Y.; Lawin, E.; Yao, B.; Oyerinde, G.; Attogouinon, A.; Afouda, A. Decreasing Past and Mid-Century Rainfall Indices over the Ouémé River Basin, Benin (West Africa). Climate 2017, 5, 74. [CrossRef] 
41. Kouakou, A.B.P.; Lawin, E.A.; Kamagaté, B.; Dao, A.; Savané, I.; Srohourou, B. Rainfall Variability across the Agneby Watershed at the Agboville Outlet in Côte d'Ivoire, West Africa. Hydrology 2016, 3, 43. [CrossRef]

42. Lawin, A.E.; Manirakiza, C.; Batablinlè, L. Trends and changes detection in rainfall, temperature and wind speed in Burundi. J. Water Clim. Chang. 2018. [CrossRef]

43. Badjana, H.M. River Basins Assessment and Hydrologic Processes Modeling for Integrated Land and Water Resources Management (ILWRM) in West Africa. Ph.D. Dissertation, Université d'Abomey-Calavi, Cotonou, Benin, 2015.

44. Kabo-Bah, A.; Diji, C.; Nokoe, K.; Mulugetta, Y.; Obeng-Ofori, D.; Akpoti, K. Multiyear Rainfall and Temperature Trends in the Volta River Basin and their Potential Impact on Hydropower Generation in Ghana. Climate 2016, 4, 49. [CrossRef]

45. Oguntunde, P.G.; Abiodun, B.J.; Olukunle, O.J.; Olufayo, A.A. Trends and variability in pan evaporation and other climatic variables at Ibadan, Nigeria, 1973-2008. Meteorol. Appl. 2012, 19, 464-472. [CrossRef]

46. Nelson, G.C.; Rosegrant, M.W.; Palazzo, A.; Gray, I.; Ingersoll, C.; Robertson, R.; Tokgoz, S. Food Security, Farming, and Climate Change to 2050: Scenarios, Results, Policy Options; International Food Policy Research Institute: Washington, DC, USA, 2010.

47. Oyerindé, G.T. Climate Change in the Niger River Basin on Hydrological Properties and functions of Kainji Lake, West Africa. Ph.D. Dissertation, Université d'Abomey-Calavi, Cotonou, Benin, 2016.

48. Badou, D.F. Multi-Model Evaluation of Blue and Green Water Availability under Climate Change in Four-Non Sahelian Basins of the Niger River Basin. Ph.D. Dissertation, University of Abomey-Calavi, Cotonou, Benin, 2016.

(C) 2019 by the authors. Licensee MDPI, Basel, Switzerland. This article is an open access article distributed under the terms and conditions of the Creative Commons Attribution (CC BY) license (http:/ / creativecommons.org/licenses/by/4.0/). 